\title{
NARRATIVAS AMAZÔNICAS: REPRESENTAÇÕES DO MITO DO BOTO NAS NARRATIVAS DOS MORADORES ANTIGOS DA COMUNIDADE DA MISSÃO TEFÉ- AMAZONAS
}

\author{
Amazonian Narratives: dolphin myth representations in Narratives of the \\ old Residents from Missão Community, Tefé-Amazonas
}

\author{
Thaila Bastos da Fonseca \\ Mestre em Ciências Humanas \\ Universidade do Estado do Amazonas, Tefé-Amazonas, Brasil \\ thailabastos@yahoo.com \\ Veronica Prudente Costa \\ Doutora em Letras Vernáculas \\ Universidade Federal de Roraima, Boa Vista, Roraima, Brasil \\ prudente.veronica@gmail.com
}

A lista completa com informações dos autores está no final do artigo

\begin{abstract}
RESUMO
As narrativas amazônicas são criações e elaborações da imaginação humana, as quais revelam elementos que precisam ser registrados e analisados dentro de um contexto amazônico. O mito é vivente e com sua verdade podemos desvendar e denunciar as realidades e os temas obscuros que foram silenciados. Posto que ele engendra o real dos fatos históricos através da simbologia, dos personagens sobrenaturais, dos deuses e dos ancestrais. Neste sentido, o presente trabalho visa, sobretudo, evidenciar a cultura da tradição oral, pois esses elementos são imprescindíveis para contribuir na construção histórica e identitária desta localidade, trazer à tona e denunciar as verdades interditas e subentendidas no contexto dessa narrativa. A pesquisa apresenta uma abordagem qualitativa e teve como base as narrativas amazônicas sobre o boto, a fim de compreender os vestígios do encontro colonial entre os povos da Amazônia e o homem branco. A problemática emergiu devido à história deste período nesta localidade ser ainda apresentada através da perspectiva do colonizador, pois são poucos os registros escritos dos nossos antepassados. Para o desenvolvimento teórico selecionamos autores como Bourdieu (2002), Eliade (2016), Slater (1994) e Thompson (1992). Assim, este trabalho contribuiu para o fortalecimento da cultura da tradição oral na Comunidade da Missão e, sobretudo, comprovamos que as histórias de encantamento permanecem vivas nas memórias de quem as narrou, revelando as verdades e as violações silenciadas neste período, que possibilitaram o entendimento das consequências do encontro colonial.
\end{abstract}

PALAVRAS-CHAVE: Narrativas Amazônicas. Encontro Colonial. Comunidade da Missão. Identidade Cultural. Mito do Boto.

\begin{abstract}
The Amazonian narratives are created and elaborated by the human imagination. They demonstrate elements, wich are necessary to be registered and analyzed in Amazonian context. This work seeks to evidence the tradicional and oral culture through an interdisciplinary perspective in Comunidade da Missão, in Tefé city, Amazonas. When people describe past events, they provide historical, social and cultural information about the place they live. This events are indispensable for historical and identity contribution about this place. This research had a qualitative approach and was based on Amazonian narration about the dolphin, seeking to comprehend the colonial meeting between tradicional people from Amazon and the white man; as weel as the erotic and virile carachteristics this mith can assume as a mythological configuration of women's opressor, victims of patriarchy. The research problem emerged due to the historical background about the community; it is still presented through the colonizer perspective, because there are few writing records from our ancestors. In order to support this research we were based on the following authors: Bourdieu (2002), Eliade (2016), Slater (1994) and Thompson (1992). This work consolidated the tradicional and oral culture in Missão, and we proved that enchantment narration is still in old people's memories. The enchantment narration show events that helped us to understand the consequences of colonial meeting, the patriarchy consolidation in our society and violence against women under masculine domination.
\end{abstract}

KEYWORDS: Amazonian Narration; Colonial Meeting; Missão Community; Cultural Identity; Dolphin Myth. 


\section{INTRODUÇÃO}

A presente pesquisa foi realizada na Comunidade da Missão, localizada à margem esquerda da Boca do Rio Tefé. É um lugar onde os moradores preservam os seus monumentos, suas tradições, seus costumes, suas crenças e valores, porém, muitos desses aspectos não eram registrados e consequentemente poderiam se perder nas memórias das pessoas antigas desta localidade. Diante do exposto, a problemática emergiu devido à história do período colonial nesta localidade ainda ser apresentada através da perspectiva do colonizador, posto que são poucos os registros escritos dos nossos antepassados, tendo em vista que, a maioria deles estão voltados para a cultura colonizadora.

A cultura da tradição oral ainda é forte entre os comunitários e as narrativas amazônicas sobre o Boto estão presentes nas reminiscências das pessoas antigas deste lugar, só precisam ser registradas, para que esses saberes sejam preservados para a posteridade. Sendo assim, questionamos: evidenciar a cultura da tradição oral através das representações do boto nas narrativas amazônicas pode contribuir para a construção identitária e histórica desta comunidade?

Deste modo, objetivamos demonstrar a importância da tradição oral para a preservação, valorização e construção da identidade cultural dentro de uma perspectiva interdisciplinar; fazer uma leitura das narrativas amazônicas sobre Boto identificando a representação social deste animal; refletir sobre a categoria erótica e viril deste personagem; identificar as consequências do encontro colonial entre o homem branco e os indígenas nessas narrativas e fortalecer a cultura amazonense na Comunidade da Missão.

Para isso, devemos pensar essas histórias como tentativa de manter uma coletividade identificada, pois conhecer uma cultura diferente é um preâmbulo para compreender e respeitar as pessoas dessa cultura e suas diferenças. Além disso, ao compreender o Outro, aprendemos mais sobre nós mesmos e sobre o que significa a pluralidade de mundos. Assim, é necessário redescobrir a tradição e mostrar as ausências, as invisibilidades, os temas que foram deixados à sombra, no obscuro, reconhecer o senso comum como parte constituinte fundamental no processo de construção do conhecimento. 


\section{AS NARRATIVAS AMAZÔNICAS E SUAS VERDADES COMO RECONSTRUÇÃO DO PASSADO}

As narrativas amazônicas estabelecem uma relação muito forte com o imaginário das pessoas que moram na Comunidade da Missão, e neste entrelaçar de histórias temos os mitos, as lendas e os contos que procedem da tradição oral. Nesse sentido, Mircea Eliade (2016) é enfático em dizer que, enquanto que os mitos se conceituam como "histórias verdadeiras" os contos e as lendas são caracterizados como "histórias falsas", pois os mitos têm a força de reconstruir o conhecimento do passado e de unir cada vez mais as pessoas às suas realidades, tendo em vista que a realidade é tão complexa e misteriosa como o mito.

O mito é vivente e com sua verdade podemos desvendar e denunciar as realidades e temas obscuros que foram ocultados, pois ele engendra o real dos fatos históricos através da simbologia, dos personagens sobrenaturais, dos deuses, dos heróis e dos ancestrais. Desse modo, Eliade (2016) destaca que o mito não é definitivamente uma teoria irreal ou uma criação fantasiosa: o mito é uma "realidade viva", porque é vivido pela sociedade e por isso é considerado verdadeiro por está estritamente relacionado à realidade das pessoas.

De acordo com esta perspectiva, ao interpretar o mito do Boto, é possível perceber os vestígios do encontro colonial entre o homem branco e as comunidades tradicionais. Identificar o tema do contato nessas narrativas implica perceber uma historicidade própria e autêntica dos povos da Amazônia e compreender os reais motivos que levaram à configuração e construção mitológica deste animal como opressor de mulheres vítimas da ação colonial. O registro escrito dessas histórias é relevante, pois ao relatarem eventos passados, os narradores realizam também uma espécie de documentação das ações que vão se constituindo através das memórias no presente. Essas ações são desencadeadas no momento em que reconstroem o passado, e por isso servirá como fatos documentais para a sociedade futura.

O sobrenatural é vivo na vida dos povos da Amazônia, a aceitação espontânea de episódios como esses é o reflexo de uma espécie de reconhecimento de dois mundos entrelaçados no cotidiano (material e simbólico), "representam um dos suportes psicológicos de compreensão de relatos verdadeiros como o do Boto". (FRAXE, 2004, p. 325) O mito do boto é uma dessas criações e elaborações da capacidade imaginativa 
desses narradores que explicam uma realidade vivenciada, não podemos afirmar que são mentiras, ilusões ou inverdades, mas são fatos que trazem à tona temas subversivos que durante muito tempo foram silenciados.

O mito está relacionado à existência e ao conhecimento da origem dos fatos, pois mergulhar no universo dos mitos nos leva a conhecer a "origem" das coisas. A narrativa mitológica, como a do boto, é capaz de trazer à tona fatos pertinentes na atualidade, pois se perpetua e está viva na humanidade, é um conhecimento "vivido" ritualmente e relembrado ou "reatualizado".

\begin{abstract}
"Viver" os mitos implica, pois, uma experiência verdadeiramente "religiosa", pois ela se distingue da experiência ordinária da vida quotidiana. A "religiosidade" dessa experiência deve-se ao fato de que, ao reatualizar os eventos fabulosos, exaltantes, significativos, assiste-se novamente às obras criadoras dos Entes Sobrenaturais; deixa-se de existir no mundo de todos os dias e penetra-se num mundo transfigurado, autoral, impregnado da presença dos Entes Sobrenaturais. Não se trata de uma comemoração dos eventos míticos, mas de sua reiteração. O indivíduo evoca a presença dos personagens dos mitos e torna-se contemporâneos deles. Isso implica igualmente que ele deixa de viver no tempo cronológico, passando a viver no tempo primordial, no Tempo em que o evento teve lugar pela primeira vez. É por isso que se pode falar no "tempo forte" do mito: é o Tempo prodigioso, "sagrado", em que algo de novo, de forte e de significativo se manifestou plenamente. Reviver esse tempo, reintegrá-lo o mais frequentemente possível, assistir novamente ao espetáculo das obras divinas, reencontrar os Entes Sobrenaturais e reaprender sua lição criadora é o desejo que se pode ler como em filigrana em todas as reiterações rituais dos mitos. Em suma, os mitos revelam que o mundo, o homem e a vida têm uma origem e uma história sobrenaturais, e que essa história é significativa, preciosa e exemplar (ELIADE, 2016, p. 22).
\end{abstract}

Podemos perceber que o mito demonstra fortemente uma relação com o mundo real, que se modifica e se incorpora à cultura das pessoas por intermédio dos elementos sobrenaturais, por isso a necessidade de falar através dele. De um modo geral, o mito tem vida, e seus acontecimentos se perpetuam na humanidade devido à profunda relação das pessoas com o imaginário e a cultura da oralidade. Neste sentido, "por ocasião da ritualização dos mitos, a comunidade inteira é renovada; ela reencontra as suas 'fontes' e revive as suas 'origens'” (ELIADE, 2016, p. 37). O mito se configura e se perpetua na humanidade por intermédio da imaginação das pessoas, ele propõe ao ser humano a capacidade de criar e a manter ativo o seu "espírito inventivo". 
O homem das sociedades nas quais o mito é uma coisa vivente vive num mundo "aberto", embora "cifrado" e misterioso. O mundo "fala" ao homem e, para compreender essa linguagem, basta-Ihe conhecer os mitos e decifrar os símbolos. Através dos mitos e dos símbolos da lua, o homem capta a misteriosa solidariedade existente entre temporalidade, nascimento, morte e ressurreição, sexualidade, fertilidade, chuva, vegetação e assim por diante (ELIADE, 2016, p. 125).

O mito tem seu poder de "verdade" e é fundamental traduzir as verdades culturais que cada ser humano carrega consigo, ou melhor, colocá-las em evidência. $O$ mito do boto é revestido de fatos e também de uma sexualidade latente e viril assentada na teoria da dominação masculina de Bourdieu, em que a supremacia androcêntrica e a submissão feminina são fortemente evidenciadas e de natural aceitação.

Trata-se da doação de meninas por seus pais a colonos portugueses em troca de alguma quinquilharia, por um lado, e a prostituição de moças por assim dizer, em troca de melhor sobrevivência na sociedade colonial (TORRES, 2017, p. 7).

De acordo com esta perspectiva, as narrativas sobre o Boto, como animal sagrado e sedutor de mulheres apresentam elementos obscuros que eram silenciados por aqueles que os praticavam. A obscuridade que percebemos no mito do boto é a vertente da dominação que reabilita virilidade e a sedução (feitiço), assentada na cultura patriarcal ocidental. A intenção certamente não é desprovida de conteúdo dominador, consiste em "encobrir a luxúria e lasciva do clero, a libertinagem e abusos sexuais dos colonos e o incesto praticado por pais biológicos com suas filhas na tenra idade" (TORRES, 2009, p.170).

O encontro colonial e a dominação masculina são evidentes nessa narrativa que "está associada à tessitura do patriarcado nas terras do Novo Mundo recémconquistadas, pelos europeus, com flagrante manipulação da mulher (enfeitiçamento) pelo boto, que a seduz e domina" (TORRES, 2009, p. 157). Neste sentido, de acordo com Lima (2013, p. 176) “A equivalência entre o boto e o homem branco é a expressão visível desse tema, reafirmada pela roupa branca, assim como o tópico da sedução e da abdução de mulheres nativas, ou a sua conquista".

Para as autoras, esse personagem encantado representa o homem branco devido às suas características descritas, como também o poder de encantar e abduzir as nativas para o seu mundo submerso. Sabe-se que, no período colonial, muitas mulheres foram 
vítimas de inúmeras violações, porém o mito do Boto era usado para encobrir a verdadeira identidade dos pais das crianças frutos de amores proibidos e incestos. A seguir, explicitaremos o motivo pelo qual escolhemos a História Oral, como método, e os procedimentos metodológicos da pesquisa.

\section{OS CAMINHOS TRILHADOS NA METODOLOGIA E A AMOSTRAGEM DA PESQUISA}

Através de uma abordagem qualitativa, e por intermédio do método da História Oral, realizamos uma ação interpretativa das narrativas amazônicas sobre o boto. Dentro desta perspectiva, buscamos fazer diferentes leituras das representações do Boto no imaginário dos moradores antigos da Comunidade da Missão. Partindo do pressuposto de que essas narrativas vão além do caráter lendário, elas engendram temas diversificados, que contribuem para o conhecimento de fatos que ficaram, por muito tempo, à margem da história, principalmente durante o período colonial. Mas antes disso, explicitaremos a importância e relevância da História Oral.

A narração oral é uma das formas mais antigas usada pelas comunidades ancestrais para perpetuação da herança, é um meio para que as tradições sejam reavivadas e ressignificadas. Ela funciona também como uma importante estratégia de identificação de comunidades tradicionais. Neste sentido, Thompson (1992, p. 44) afirma que:

A história oral é uma história construída em torno de pessoas. Ela lança a vida para dentro da própria história e isso alarga seu campo de ação. Admite heróis vindos não só dentre os líderes, mas dentre a maioria desconhecida do povo. Traz a história para dentro da comunidade e extrai a história de dentro da comunidade.

Isso comprova que o ato de narrar é uma prática social e essas narrativas foram construídas e contadas pelas pessoas através do tempo na própria comunidade. Foram passadas de boca em boca, nas noites de lua cheia, nos assoalhos das casas, nos terreiros de barro vermelho, nos girais de "paxiúba" e sob a luz de "lamparinas e porongas". Este método nos possibilitou utilizar a memória e reconhecê-la como uma das mais importantes fontes, o qual proporcionou vez e voz àqueles que, ao longo do tempo, foram oprimidos, esquecidos, menosprezados ou ofuscados pelo poder da classe dominante que sempre tentou impor suas diretrizes alienáveis. 
Neste sentido, gostaríamos de colocar em evidência a questão desta tentativa de silenciamento das culturas locais e da imposição da cultura colonizadora a partir da concepção do autor Sérgio Buarque de Holanda, o qual, na sua obra Raízes do Brasil, faz uma leitura crítica acerca do processo colonial no Brasil:

A tentativa de implantação da cultura europeia em extenso território, dotado de condições naturais, se não adversas, largamente estranhas à sua tradição milenar, é, nas origens da sociedade brasileira, o fato dominante e mais rico em consequências. Trazendo de países distantes nossas formas de convívio, nossas instituições, nossas ideias, e timbrando em manter tudo isso em ambiente muitas vezes desfavorável e hostil, somos ainda hoje uns desterrados em nossa terra (HOLANDA, 1995, p. 31).

Desse modo, muitos aspectos das culturas locais foram silenciados devido à tentativa de imposição da cultura colonizadora, e isso acarretou consequências e perdas irreparáveis. Em contrapartida, grande parte dessas narrativas e temas que ficaram à margem da história foram transmitidos de geração a geração, por intermédio da oralidade. Elas resistiram e persistem nas reminiscências das pessoas mais experientes, na tentativa de manter uma coletividade identificada, de ressignificar aspectos historiográficos e de escrever a história a partir da perspectiva dos moradores da Comunidade da Missão é que esta pesquisa se configura e se torna relevante.

Ao se trabalhar a História Local, possibilitamos às pessoas a compreensão do passado e do presente, levando-as à construção de sua identidade. Essa temática permite que o pesquisador parta das histórias individuais e dos grupos, inserindo-as em contextos mais amplos. Com a abordagem da História Oral, as pessoas passam gradativamente a observar e perceber os aspectos culturais do local onde vivem ressignificando, registrando e valorizando-os.

Neste sentido, é importante destacar que os moradores da Comunidade da Missão são agricultores e vivem basicamente de tudo aquilo que produzem, eles caçam, pescam, plantam, produzem seu alimento, mas para comprar outros utensílios necessários para o convívio diário de uma família, levam seus produtos e vendem na Feira Municipal de Tefé. A agricultura familiar é forte no local, pois as famílias plantam, colhem e compartilham entre si. A produção de farinha é realizada por quase todos os comunitários, que têm roçado. E quando suas roças "vingam", os mesmos realizam o ajuri (trabalho em conjunto) para não perderem a produção. Holanda (1995, p. 60) descreve esse trabalho em conjunto: 
[...] como muxirão ou mutirão, em que os roceiros se socorrem uns aos outros nas derrubadas do mato, nos plantios, nas colheitas, na construção de casas, na fiação do algodão, teriam sido tomados de preferência ao gentio da terra e fundam-se, ao que parece, na expectativa de auxílio recíproco, tanto quanto na excitação proporcionada pelas ceias, as danças, os descantes e os desafios que acompanham obrigatoriamente tais serviços.

Assim, são nesses momentos de convívio com o outro, de ajuda recíproca, de partilha e troca de trabalhos, que as narrativas amazônicas se fazem presente. Os ajuris, como são conhecidos os trabalhos coletivos, são as poucas ocasiões em que as histórias oriundas do imaginário popular, de personagens lendários, são evidenciadas, compartilhadas e contadas de acordo com a capacidade imaginativa de seu narrador.

São nesses encontros que os moradores tornam protagonistas, autores e narradores de suas histórias, ouvidas de uma ancestralidade e compartilhadas entre seus pares. São histórias de contextos diversos, mas muito significativas para quem as narram. Dentro desta perspectiva, partindo do pressuposto de que as pessoas que fazem parte de trabalhos coletivos como esses são os moradores mais experientes e mais antigos, é que a escolha dos sujeitos envolvidos na pesquisa foi definida.

Desse modo, focalizamos as representações do mito do boto no imaginário dessas pessoas, e decidimos escolher as pessoas com mais experiência de vida, pois eles trazem consigo todo um arcabouço histórico, social e cultural das suas ancestralidades em suas reminiscências. Eles acreditam que os personagens mitológicos são protetores e também exercem uma influência significativa na natureza, e consequentemente nas ações humanas, principalmente as narrativas de personagens lendários.

Colocar em evidência toda e qualquer forma de conhecimento é mostrar para a academia que os povos tradicionais da Amazônia produzem saberes que precisam ser ouvidos, lidos, analisados e enaltecidos dentro de uma perspectiva científica. É mostrar também a riqueza de saberes que a história oral nos propicia quando nos rendemos a ela, e que as pessoas podem sim ser os protagonistas de suas histórias.

Neste sentido, escolhemos como amostra de pesquisa 10 moradores antigos, cuja faixa etária varia entre 60 a 90 anos, sendo cinco homens e cinco mulheres. Selecionamos as pessoas mais idosas, essa escolha se justifica também pelo fato de elas terem mais experiência de vida e mais histórias para contar, pois as mesmas são como um livro, quando partem para outra dimensão se fecha para sempre. Consideramos relevante privilegiar as narrativas dessas pessoas por já possuírem uma vasta memória, 
pois "se o adulto não dispõe de tempo ou desejo para reconstruir a infância, o velho se curva sobre ela como os gregos sobre a idade de ouro" (BOSI, 1994, p. 83).

Os nomes dos entrevistados não estão expostos nas transcrições, mas utilizamos o seguinte sistema numérico de identificação para distinguir uma fala da outra e manter uma postura ética perante os sujeitos entrevistados. Assim teremos: morador 1, morador 2, morador 3, morador 4 e morador 5, para os cinco homens entrevistados e moradora 6 , moradora 7, moradora 8, moradora 9 e moradora 10, para as cinco mulheres.

A seguir, explicitaremos as leituras das narrativas coletadas dos moradores antigos da Comunidade da Missão. Elas apresentam enredos diversos, em contrapartida, serão a temática do encontro colonial e androcêntrica que colocaremos em evidência, como também de que maneira essas temáticas são representadas no imaginário de quem as narrou.

\section{O BOTO COMO CONFIGURAÇÃO MITOLÓGICA E HISTÓRICA DO ENCONTRO COLONIAL}

A maioria dos textos coletados acerca do mito do boto apresenta-o como um animal que se transforma em um belo homem branco sedutor de mulheres e donos de cidades submersas, ele seduz e encanta pessoas para seu mundo. São narrativas que engendram verdades vividas e acontecimentos ocorridos por pessoas que acreditam ou presenciaram tais fatos. Lima (2013) destaca também que outra visão pessimista sobre o contato é dada pela mensagem de perigo, de risco de abdução de indivíduos para outro mundo, a cidade submersa do encante ou o mundo do fundo. Nesta cidade, os botos são dono de castelos, onde as pessoas que foram encantadas vivem como escravos e as moças são escravas sexuais. Assim:

Os encantados são seres dotados do poder de transformação entre um corpo animal e um corpo humano, que é o meio pelo qual se manifestam e estabelecem comunicação com as pessoas. Costumam aparecer em festas e seduzir as moças com quem dançam. Apesar de não serem claramente malignos (mas sim malinos, uma expressão próxima do sentido de travesso ou traquina), os botos representam perigo porque podem atrair a pessoa para a cidade do encante, onde moram, descrita como muito iluminada e magnificente, localizada no fundo do rio (LIMA, 2013, p. 177). 
Para a autora, as histórias sobre o boto pertencem a uma "construção cosmológica mais extensa, porém frouxa, e têm como base a noção de encante, os seres encantados e o lugar onde vivem, na cidade do fundo dos rios." (LIMA, 2013, p. 177) Os botos são travessos porque têm o poder de, com sua força, "espantar pescadores que quisessem entrar em um lago. Mordia remo, quilha de canoa, espantava os peixes e mostrava objetos assombrados".

Ninguém tem coragem de flechar um boto por causa do seu encanto, pois o boto quando vê um pescador sozinho gosta de atormentá-lo, para isso, mostram cabelos, galhos de árvores, caveira de animais e até cruz, traz do fundo para a superfície. Porque são travessos e traquinas e gostam de perturbar os pescadores nos momentos de suas pescas. Dentro desta perspectiva, a moradora 7 nos relatou assim:

Meu pai me contou que um dia um homem atou sua malhadeira, tirou o tabaco da lata de tabaco e começou a mascar. Só de "butuca", ele espera a "broca", mas o boto começou a boiar fazendo uma zoada medonha e espantando os peixes dali e tentou virar sua canoa. $O$ pescador ficou matutando, e com a peixeira afiada esperou o boto se enrolar na malhadeira. Depois disso, o homem foi se achegando e tacou a peixeira no boto, mantando o animal. Na mesma hora começou a formar um temporal medonho e o homem agasalhou as suas coisas e pegou o rumo de casa. $\mathrm{Na}$ primeira noite o homem tentava dormir, mas não conseguia, a rede do homem balançava e ele não tinha sossego pra dormir. E toda noite era essa arrumação, o homem queria dormir e não podia, ficou doido minha filha, porque o feitiço do boto é cruel. Até que um dia, não aguentando mais aquela vida de perseguição, correu "pro rumo" do rio e nunca mais voltou, ficou pagando penitência na terra do encante (Entrevista realizada dia 20 de Outubro de 2017).

É uma tradição dos botos provocar medo e tentar virar a canoa dos pescadores. Lima (2013) destaca que isso ocorre pelo fato de os botos serem animais "malinas" e "gaiatos", ou pelo simples fato de encantar o pescador e levá-lo para seu mundo, para viver como subordinado. Os botos têm poderes sobrenaturais de afugentar os pescadores que invadem o seu espaço. Eles começam a fazer barulho para atrapalhar as pescas, ninguém tem coragem de arpoá-los, pois tem medo dos feitiços que consequentemente sofreriam por ferir os cetáceos.

Diante disto, Slater (1994, p. 134) afirma que: "quem mata um boto pode ficar "panema", ou seja, pode ser atacado por uma incapacidade sobrenatural, sobretudo, na caça e na pesca. Se a vítima for um encantamento em forma de animal, as consequências podem ser piores". Na narrativa em destaque, o homem que tirou a vida 
do boto enlouqueceu e, como penitência, viveria como escravo na terra do encante. A expressão utilizada pela narradora, "pagar penitência", significa que o homem serviria aos seus senhores (os botos) para toda a eternidade. Percebemos aqui marcas do período colonial, principalmente quando são submetidos ao trabalho servil por toda a eternidade.

O rio em que o pescador se encontrava no momento em que o boto apareceu é de fato o lugar do pescador, e de onde os povos da Amazônia retiram seu alimento. Isto comprova que, quem teve o espaço invadido foi o homem e não o boto, este cenário representa a ação colonial nos territórios colonizados. Quando o colonizado age contra este regime, é penalizado com a morte. O encantamento além de escravizar implica também romper com todos os vínculos sociais no mundo terreno e viver em outro mundo, correndo o risco de nunca mais retornar.

Outro fator recorrente entre os moradores, e que é corriqueiro, é ouvir reclamações sobre o boto que, por pura "traquinagem", impede os mesmos de pescarem, pois quando os botos avistam uma malhadeira atada no igapó, se reúnem grupalmente, "boiam", fazem "zuada" e tentam alagar a canoa. Os pescadores tentam arpoar o animal, mas quando o acertam, pegam feitiços e não retornam mais a sanidade mental e são severamente castigados com a morte, ou a prisão servil na cidade do encante. Neste sentido, convém destacar a narrativa da moradora 8:

Certo dia uma família vinha atravessando o rio debaixo "dum" temporal medonho, como a canoa era pequena não conseguiram continuar a viagem e a canoa acabou se alagando, com o acidente só conseguiram salvar- se os dois filhos e a esposa, o pai das crianças desapareceu misteriosamente no rio.

Por vários dias a mulher e os filhos choraram inconsoladamente a perca do ente querido. Certo dia, o homem apareceu do nada no meio do rio e começou a conversar com um pescador que ali remava. $\mathrm{O}$ estranho que ele só apareceu da cintura para cima, a metade do corpo permanecia o tempo todo dentro da água.

O pescador ouvia atentamente o que o homem Ihe falava:

- Após o acidente, um boto acorrentou-me pelos pés, para que eu não pudesse escapar.

-E o que há lá pro rumo debaixo? - Perguntou o pescador.

- Lá no fundo do rio há uma grande cidade, onde os botos são os grandes senhores das profundezas. Quando o boto chegava a casa, ele retirava seu anel e transformava-se em homem como nós. Meu avô que era pescador e ouviu essa história daquele homem sofrido falou também que um dia o homem criou coragem, quebrou a corrente e colocou o anel do boto em seu dedo, assim transformando-se em um boto encantado. Com isso, ele teve a chance de visitar sua família na superfície, explicar que fora encantado pelo boto e depois voltou para o rio, pois lá era seu novo lar (Entrevista realizada dia 29 de Outubro de 2017). 
Nesta passagem, notamos que este ser mitológico representa o colonizador no período da colonização podendo ser comprovado na seguinte passagem: "Lá no fundo do rio há uma grande cidade, onde os botos são os grandes senhores das profundezas". Posto que, chegavam a determinado lugar, apropriavam-se dele, colonizavam como se fossem os verdadeiros "donos" daquela terra e então demonstravam através de atos violadores, a supremacia do colono, pois mantinham como escravos aqueles que encontravam. Nesta perspectiva, Cesáire (1975) diz que o colonizador se utiliza de um discurso repressor que, além de negar a cultura do colonizado, enfatiza que o único modelo predominante e que deve ser seguido é a cultura do colonizador. $\mathrm{O}$ autor reafirma ainda:

[...] a colonização desumaniza, repito, mesmo o homem mais civilizado; que a ação colonial, a empresa colonial, a conquista colonial, fundada sobre o desprezo pelo homem indígena e justificada por esse desprezo, tende, inevitavelmente, a modificar quem a empreende; que o colonizador, para se dar boa consciência se habitua a ver no outro o animal, se exercita a rata-lo como animal, tende objetivamente a transforma-se, ele próprio, em animal (CÉSAIRE, 1978, p.24-25).

No contexto da narrativa da entrevistada, constatamos que o colonizador personificado pelo boto desumaniza o colonizado, representado pelo pescador. Nesta passagem: "um boto acorrentou-me pelos pés, para que eu não pudesse escapar", é evidente que o colonizador se restringe a um ser animalizado, abdicando de sua condição humana, para atuar na ação colonial, visto que, a colonização tem o poder de desfigurar a humanização do ser humanizado. Neste sentido, entre o colonizador e o colonizado, só há lugar para o trabalho forçado, a intimidação, a opressão, as culturas obrigatórias, "as relações de dominação e de submissão que transformam o homem colonizador em chicote e o homem indígena em instrumento de produção" (CESAIRE, 1978, p. 25).

Durante o período colonial, muitas vozes foram silenciadas, sociedades indígenas dizimadas e barbáries justificáveis através dos discursos ideológicos criados pelos colonizadores, com o objetivo de oprimir e explorar os colonizados. Na narrativa, percebemos que quando o boto atua na ação colonial, na cidade do encante, é prazeroso ver o outro (homem) como animal, pois o acorrenta e mantém-no como vassalo. E acima de tudo, apresenta excitação, em tratá-lo como tal, desprezando o homem indígena, como também sua cultura, seus costumes, suas crenças e tradições, característica marcante do colonialismo. Neste sentido, torna-se relevante ressaltar que o mito do boto revela 
verdades do período colonial, como a opressão e barbáreis justificáveis, para demonstrar a "supremacia" do colonizador na ação colonial.

Em contrapartida, à medida que o colonizado reconhece a sua força e o seu poder que the foi negado, começava a compreender que o papel exclusivo do colonizador era de tornar impossível os seus sonhos de liberdade. "Durante a colonização, o colonizado não cessa de se libertar entre nove horas da noite e seis horas da manhã" (FANON, 2005, p. 39). De acordo com esta perspectiva, a partir do momento que o colonizado sai de sua condição e reconhece que sua vida não se difere da do colonizador, está pronto para lutar e apropria-se de tudo aquilo que Ihe foi tirado não restando alternativa ao colonizador, o que the resta é fugir. Assim: “... um dia o homem criou coragem, quebrou a corrente e colocou o anel do boto em seu dedo, assim transformando-se em um boto encantado".

Lima (2013) destaca que é preciso se manter em alerta para não travar relação de comensalidade naquele domínio relacional, principalmente em um lugar que não é o seu. Ser enganado por esse outro mundo pode levar a uma perda de si. Apesar do homem, cativo do boto, na cidade submersa, criar coragem e por intermédio do anel transformarse em boto também. Ele não percebeu que o encantamento não tinha sido quebrado, sem perceber o perigo, ocasionou a perda de si. Assim: "ele teve a chance de visitar sua família na superfície, explicar que fora encantado pelo boto e depois voltou para o rio, pois lá era seu novo lar".

As histórias oriundas do imaginário popular, enquanto narrativas dos tempos ancestrais, como é o exemplo da coletada acima, revelam que as ações dos seres sobrenaturais interferem no mundo, mudando realidades em outras. Trata-se de um movimento em direção à redescoberta de uma força oculta, o ser divino, sobrenatural, que atua para fazer ressurgir seres, como também para exortá-los e ensiná-los. São realidades que passam a existir na natureza sem que o homem arcaico pudesse encontrar explicações terrenas para o aparecimento de tal coisa.

O mito do boto revela também temáticas que encobriam a luxúria e a lascividade de homens que utilizavam da situação patriarcal para praticar relações fora dos laços matrimoniais e incestos. Esta narrativa engendra fatos históricos e reais como é o exemplo da narrativa a seguir:

Minha mãe era professora e ela me contava que as pessoas contavam a lenda do boto para amedrontar as mulheres. Mas ela disse que acontecia muita coisa errada e triste, as mulheres fugiam de casa e iam tentar uma nova vida em Tefé, trabalhando nas casas alheias em troca muitas vezes 
de apenas um prato de comida. E quando perguntavam ao pai o porquê da filha ter ido embora, o pai dizia que era por causa de macho. Mas não era nada disso, tinha homem muito ruim naquela época. Homens que "mexiam" com as próprias filhas, a senhora sabe o que "tô" querendo dizer. Mas isso do boto não é lenda não, foi criado para esconder o verdadeiro pai dos filhos dessas mulheres. Diziam que era culpa do pobre do boto, onde já se viu minha filha, um boto fazer filho igual a gente "num" tem como não. Eu só sei que minha mãe falava que muita das vezes o pai das crianças eram os próprios tios, ou o avô. Às vezes, as famílias entregavam os filhos do boto para ajudarem os padres na igreja como coroinhas. $E$ era pior, porque a senhora pode imaginar o que acontecia né... É por isso que eu não gosto desse negócio de viver socado dentro de igreja, é de desconfiar. Nunca deixei meus filhos largados no mundo e nem pra ninguém cuidar, pois como minha mãe me contava, muita coisa ruim acontecia, cruz credo (Entrevista realizada dia 20 de Outubro de 2017, com a moradora 9).

Percebemos neste relato a supremacia androcêntrica, pois "a violência se institui por intermédio da adesão que o dominado não pode deixar de conceder ao dominante" (BOURDIEU, 2002, p. 23), porque a força masculina dispensa justificativa, tendo em vista que a visão androcêntrica foi se impondo de forma naturalizada que as pessoas concebem como natural. Para o autor, a ordem masculina é favorecida pela confirmação constante do funcionamento da sociedade, que constrói o corpo como uma realidade sexuada, seguidora de princípios de divisão sexualizante. Isto quer dizer que o corpo é construído socialmente e é a concepção sexuada do mundo que transfere ao corpo a diferença entre os sexos, que edifica a segmentação entre os gêneros a partir de uma visão mítica ancorada na relação arbitrária de dominação masculina sobre as mulheres.

Neste sentido, na ação colonial as violações eram justificadas, sobretudo, através de um discurso opressor utilizado pelo dominador, e isso incluía também abusar sexualmente das mulheres e engravidá-las para não assumir a paternidade. Vale frisar que a maioria dos violadores eram membros da família dessas mulheres e homens casados, o crime era encoberto através da construção do mito do boto, pois a identidade do opressor não poderia ser revelada. Isso comprova a dominação masculina sobre as moças em situação de violência, que por não terem para onde ir confirmavam a versão mitológica.

Além da dominação masculina, na fala da narradora podemos evidenciar a suspeita de incesto, pois: "acontecia muita coisa errada e triste, as mulheres fugiam de casa e iam tentar uma nova vida em Tefé. E quando perguntavam ao pai o porquê da filha ter ido embora, o pai dizia que era por causa de macho". É nesta perspectiva que Eliade (2016) afirma que o mito é uma "realidade viva", e atravessa gerações, pois crimes de 
abusos sexuais são pertinentes e recorrentes em nossa sociedade atual, uma vez que a maioria dos molestadores são os próprios membros da família como pais, irmãos, tios e primos. Desse modo, os frutos da violação e do incesto eram entregues para a igreja pela própria família, numa tentativa de silenciar a verdadeira identidade do pai da criança, que passava a ser conhecida como o filho do boto.

Segundo a entrevistada, a Igreja acolhia essas crianças na tentativa de "protegêlos" do Boto, pois quando um filho do boto "vinga", eles sobem à superfície terrena para buscá-lo. Assim, para livrarem essas crianças das garras dos encantados, os padres acolhiam-nas na Igreja, que de acordo com a entrevistada "é o único lugar que os botos não entram, porque eles têm medo de cruz".

Torres (2017) destaca que com o advento de instituições religiosas, tais como os jesuítas e carmelitas, em prol de propagar a fé cristã do verdadeiro Deus na Amazônia, sinalizou para o aumento de clérigos e as sexualidades contidas e proibidas. Neste sentido, consideramos relevante recorrermos a autora, pois: "trata-se da doação de meninas por seus pais a colonos portugueses em troca de alguma quinquilharia, por um lado, e a prostituição de moças por assim dizer, em troca de melhor sobrevivência na sociedade colonial" (TORRES, 2017, p. 7). Esse aspecto identificamos na fala da entrevistada, pois a mesma nos revela que "Às vezes, as famílias entregavam os filhos do boto para ajudarem os padres na igreja como coroinhas. E era pior, porque a senhora pode imaginar o que acontecia né".

Narrativas e relatos de desaparecimentos misteriosos de pessoas são comuns na Comunidade, pois o rio é um mar de mistérios. Partindo desse pressuposto, a entrevistada 10 nos relatou:

Minha avó me falava que um dia a irmã dela tinha sido encantada pelo boto. Todo santo dia, quando chegava a "boca da noite" a mãe delas dizia: não quero ninguém na beira do rio de noite, vocês não teimam, porque tem muita "mizura" neste rio que a gente não conhece. E minha tia-avó, irmã de minha vó gostava de pular n'água este horário. A mãe dela já tinha proibido, mas "num" tinha jeito, quando chegava a "boca da noite", a mulher endoidava "pra" ir "pro" rio e não tinha quem segurasse. Até que um santo dia, num descuido quando deram fé a mulher já tinha sumido "pro" rumo do rio e nunca mais voltou. Foi feitiço minha filha, ela endoidava pra entrar na água tirava a roupa e tudo, até que nunca mais voltou (Entrevista realizada dia 22 de Novembro de 2017).

O boto tem poderes de encantamento que podem levar à loucura, assim como ao suicídio que é evidente na narrativa acima. Os horários em que os cetáceos costumam 
enfeitiçar ocorrem por volta do entardecer, às seis horas da tarde, com o intuito de levar para o fundo do rio a moça que o atraiu sexualmente. É um perigo, pois são envolvidas com uma paixão avassaladora, através do poder de encantamento do boto, que sob a perspectiva da entrevistada, leva à loucura. Eventos de pessoas que somem no rio são comuns na Amazônia, e a grande maioria delas, são mulheres. As que são levadas "de corpo" desaparecem e não há uma explicação plausível para isso, é inexplicável, simplesmente acontece. Muitos corpos desapareceram e a narradora associa este sumiço ao feitiço do boto.

Na concepção dos moradores antigos da Comunidade da Missão, o encontro com os seres de encantamento (os botos) acontece como uma resposta da "Mãe Natureza" aos seus filhos. Quando uma pessoa some misteriosamente, sem deixar vestígios, é porque algo ruim cometeu, como por exemplo, desmatar a mata, matar bicho, ou arpoar botos, e como castigo, desaparece. Para eles, os botos veem os humanos da mesma maneira que os humanos os veem, e assim quando um homem arpoa um boto, o boto vem à superfície e os encanta, levando-o para a cidade submersa. Para esses moradores, é a lei da natureza, pois "colhemos o que plantamos minha filha".

Portanto, as análises dessas histórias são necessárias para entendermos que conhecer uma cultura diferente é uma forma de compreender e respeitar as pessoas dessa cultura e suas diferenças, como também pensar as narrativas amazônicas como forma de ressignificação, construção das identidades, preservação e reescrita da história.

\section{CONSIDERAÇÕES FINAIS}

Com esta pesquisa, percebemos que as criações populares como os mitos, agregam verdades históricas que, ao interpretarmos, trouxemos à tona os vestígios do período colonial na perspectiva do colonizado. Revelam também saberes e entendimentos acerca de uma realidade vivida entre as pessoas e, sobretudo, as verdades subentendidas e interditas sobre as mulheres e crianças vítimas da violação na ação colonial. Essas mulheres sofreram e ainda sofrem assédios sexuais de homens casados, irmãos, primos, padrastos, padres e inclusive dos pais biológicos. $\mathrm{O}$ mito se configura como forma de expressão de um todo, ele representa uma coletividade, que no 
caso de nossa pesquisa, denuncia as realidades da opressão pertinente no encontro colonial e os abusos sexuais contra mulheres e crianças.

Assim como a violação do patriarcado, as narrativas amazônicas são capazes de trazer à luz, o impacto e as consequências do encontro de duas culturas, a colonizadora e a colonizada. A eurocêntrica, moldada na estrutura patriarcal, pois os filhos do boto, frutos da violação contra a mulher, eram bem aceitos nas comunidades, para encobrir as relações proibidas e os incestos. E a cultura indígena pautada na crença em seres encantados e animais dotados de poderes sobrenaturais.

Mas o que pode contribuir para o enfraquecimento desta tradição? Com o crescimento populacional os seres encantados têm se afastado das pessoas, pois a efetivação de sua existência depende muito da crença nesse ser sobrenatural. A diminuição de contação de histórias como a do boto é fato, mas, com este trabalho, comprovamos que as experiências e as histórias de encantamento permanecem vivas no imaginário de quem as narrou. Assim, contribuímos para a perpetuação de uma herança e para a evidenciação da cultura local, pois a arte de narrar se revigora e se fortalece.

\section{REFERÊNCIAS}

BOSI, Ecléa. Memória e Sociedade: lembranças de velhos. São Paulo: Companhia das Letras, 1994.

BOURDIEU, Pierre. A dominação masculina. Rio de Janeiro, 2002.

CESAIRE, Aimé. Discurso sobre o colonialismo. Lisboa: Sá da Costa Editora, 1978. [1950]

ELIADE, Mircea. Mito e Realidade. São Paulo: Perspectiva, 2016.

FANON, Frantz. Os condenados da terra. Juiz de Fora: Ed. Da UFJF, 2005. [1961]

FRAXE, Terezinha. Cultura cabocla-ribeirinha: mitos, lendas e transculturalidade. São Paulo: Annablume, 2004.

HOLANDA, Sérgio Buarque de. Raízes do Brasil. 26 ed. São Paulo: Companhia das Letras, 1995.

LIMA, Deborah. O homem branco e o Boto: o encontro colonial em narrativas de encantamento e transformação (Médio Rio Solimões, Amazonas). Teoria \& Sociedade, (no prelo). 2013.

SLATER, Candance. Dance of the Dolphin: Transformation and disenchantment in the Amazonian imagination. Chicago e Londres: University of Chicago Press, 1994. 
THOMPSON, Paul. A voz do passado: história oral. Rio de Janeiro: Paz e Terra, 1992. [1978]

TODOROV, Tzvetan. A conquista da América: a questão do outro / Tzvetan Todorov; tradução Beatriz Perrone Moisés. - 4⿳亠丷a . ed. - São Paulo: Editora WMF Martins Fontes, 2010. - (Biblioteca do pensamento moderno).

TORRES, Iraildes Caldas. Arquitetura do poder; memória de Gilberto Mestrinho. Manaus: Edua, 2009.

TORRES, Iraildes Caldas. Ritual pagão do Boto na Amazônia brasileira: feitiço e gravidez. Manaus-UFAM, 2017.

\section{NOTAS}

Thaila Bastos da Fonseca

Mestre em Ciências Humanas

Universidade do Estado do Amazonas, Programa de Pós-Graduação Interdisciplinar em Ciências Humanas, Tefé-

Amazonas, Brasil.

thailabastos@yahoo.com

Veronica Prudente Costa

Doutora em Letras Vernáculas

Universidade Federal de Roraima, CCLA, Boa Vista, Roraima, Brasil.

prudente.veronica@gmail.com

Endereço de correspondência do principal autor

Rua Minas Gerais, n 701, Bairro: Monte Castelo, CEP: 69557-045, Tefé, Amazonas, Brasil. País.

\section{AGRADECIMENTOS}

Agradecemos aos moradores antigos da Comunidade da Missão, que contribuíram satisfatoriamente para a construção deste trabalho fornecendo suas reminiscências acerca da temática retratada na presente pesquisa, ao Programa de pós-graduação Interdisciplinar em Ciências Humanas e a todos que contribuíram direta e indiretamente neste processo.

\section{CONTRIBUIÇÃO DE AUTORIA}

Concepção e elaboração do manuscrito: T. B. Fonseca, V. P. Costa.

Coleta de dados: T. B. Fonseca, V. P. Costa.

Análise de dados: T. B. Fonseca, V. P. Costa.

Discussão dos resultados: T. B. Fonseca, V. P. Costa.

Revisão e aprovação: A. P. Sobrenome

Caso necessário veja outros papéis em: https://casrai.org/credit/

\section{CONJUNTO DE DADOS DE PESQUISA}

Todo o conjunto de dados que dá suporte aos resultados deste estudo foi publicado no próprio artigo.

\section{FINANCIAMENTO}

Não se aplica.

\section{CONSENTIMENTO DE USO DE IMAGEM}

Não se aplica

\section{APROVAÇÃO DE COMITÊ DE ÉTICA EM PESQUISA}

A pesquisa teve aprovação do comitê de ética com o número do CAAE: 92150418.0.0000.5016, parecer de número: 3.140.862 e data de aprovação 11/022019. 


\section{CONFLITO DE INTERESSES}

Não se aplica

LICENÇA DE USO - uso exclusivo da revista

Os autores cedem à Revista Internacional Interdisciplinar INTERthesis os direitos exclusivos de primeira publicação, com o trabalho simultaneamente licenciado sob a Licença Creative Commons Attribution (CC BY) 4.0 International. Estra licença permite que terceiros remixem, adaptem e criem a partir do trabalho publicado, atribuindo o devido crédito de autoria e publicação inicial neste periódico. Os autores têm autorização para assumir contratos adicionais separadamente, para distribuição não exclusiva da versão do trabalho publicada neste periódico (ex.: publicar em repositório institucional, em site pessoal, publicar uma tradução, ou como capítulo de livro), com reconhecimento de autoria e publicação inicial neste periódico.

PUBLISHER - uso exclusivo da revista

Universidade Federal de Santa Catarina. Programa de Pós-graduação Interdisciplinar em Ciências Humanas. Publicação no Portal de Periódicos UFSC. As ideias expressadas neste artigo são de responsabilidade de seus autores, não representando, necessariamente, a opinião dos editores ou da universidade.

EDITORES - uso exclusivo da revista

Javier Ignacio Vernal, Silmara Cimbalista e Selvino José Assmann (In Memoriam).

EDITOR ASSISTENTE - Eixo temático: “Amazônia: povos, conflitos e preservação” Luiz Barp

HISTÓRICO - uso exclusivo da revista

Recebido em: 21-11-2019 - Aprovado em: 18-05-2020 - Publicado em: 08-06-2020 